The University of Akron

\title{
IdeaExchange@UAkron
}

Proceedings from the Document Academy

University of Akron Press Managed

June 2017

\section{Documents, Futures: Palm Reading, Palmyra Leaves, and Planetary Prophesy}

Bhuva Narayan

University of Technology Sydney, bhuva.narayan@uts.edu.au

Please take a moment to share how this work helps you through this survey. Your feedback will be important as we plan further development of our repository.

Follow this and additional works at: https://ideaexchange.uakron.edu/docam

Part of the Library and Information Science Commons, and the Regional Sociology Commons

\section{Recommended Citation}

Narayan, Bhuva (2017) "Documents, Futures: Palm Reading, Palmyra Leaves, and Planetary Prophesy," Proceedings from the Document Academy: Vol. 4 : Iss. 1 , Article 18.

DOI: https://doi.org/10.35492/docam/4/1/18

Available at: https://ideaexchange.uakron.edu/docam/vol4/iss1/18

This Article is brought to you for free and open access by University of Akron Press Managed at IdeaExchange@UAkron, the institutional repository of The University of Akron in Akron, Ohio, USA. It has been accepted for inclusion in Proceedings from the Document Academy by an authorized administrator of

IdeaExchange@UAkron.For more information, please contact mjon@uakron.edu, uapress@uakron.edu. 


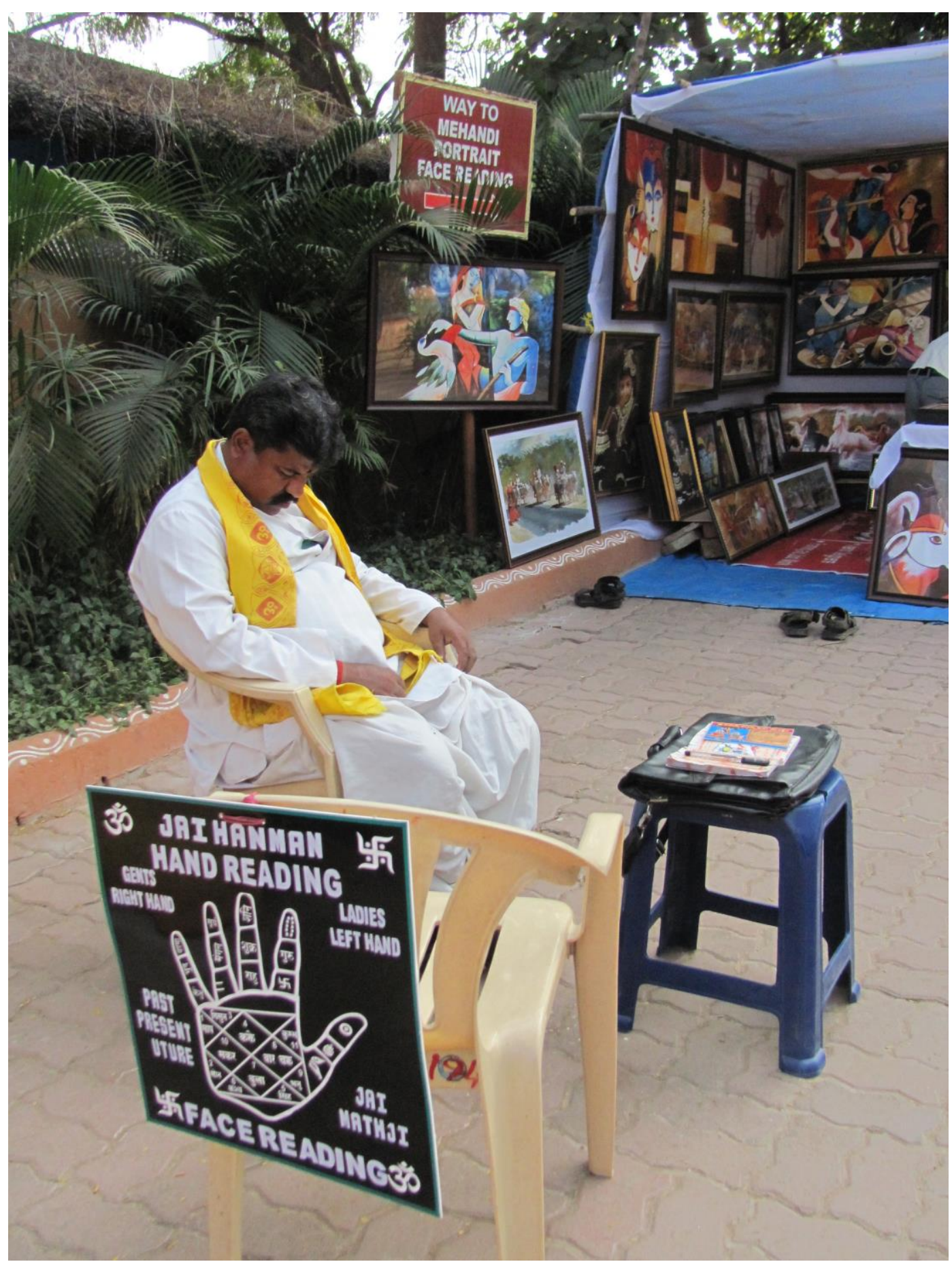




\section{4}

I sit on the porch all morning, playing with friends and watching the street. A passing parade of street vendors and peddlers of all kinds push their wagons and carts. Among the passing sounds of an occasional car, there is a silence that is broken only by the Kudu-kudu-pandi, the mobile fortune-teller dressed in flowing robes and a turban, and accompanied by a bull-mascot we call Bwoom Bwoom Cow. He comes to every house and loudly cries a sing-song astrological prediction for the day to the rhythm of a hand-drum that goes bwoom bwoom in monotonic beat. The bull has bells and colorful ribbons trailing down from his horns. He shakes his head in agreement to the rhythm of the drum, as if to confirm his master's divination.

"A good day dawns for you, sir. A good day dawns for you, madam," is his usual prediction, to which he adds some interesting detail which fits the amount of money my grandmother gives him - "Moon in Libra, Saturn in Cancer, Sun in Taurus, Venus in Gemini, Pluto in Pisces; today is a good day for starting a new venture." On this day, he tells my grandmother that she will have a near and dear one come home from afar. I'm sure he had heard the word on the streets that my uncle was coming home!

\section{2}

There was an old man on the train, and everybody was extending their hands towards him eagerly, anxiously, as if they were waiting for him to give them something. He "read" their palms one by one, like turning the pages of a book. When my turn came, I put out my dirty little hand, full of blue stains from the fountain pen I had recently learned to use, and covered with the sticky sweet liquid from the gulab jamun I had greedily munched on. He took my palms gently and laid it on his huge left hand, pointed to the lines on my palm with his right index finger and said, "My, what dark lines. You must do a lot of thinking... Do you read a lot?" I eagerly nod my head while my grandmother gloats over me, proudly looking around at everybody in the compartment. All of a sudden I realize that he should be telling me things, not asking me questions. I decide to keep quiet and be shy. "Well, you are a very good student and will do very well in your studies." I had just failed a math test. My grandmother was taking me over to spend my summer holidays being tutored by my uncle so I could get into sixth grade without losing a year. It had been my first year at school, for I had refused to go to school before, so my parents found a home tutor for me. The teacher was wonderful; she spent most of the time just talking over the fence with the neighbor, while I was only too happy to play in the garden. The old man goes on reading my palm: "You will live a long and happy life and will be prosperous and have lots of children." My grandmother is so pleased that she hands the man the box of sweets that she's carrying for my uncle, with a silver coin to boot. I already start planning how I should live the rest of my life disproving his prophecy. 


\section{0}

I walk into the little tent of the palm-reader at the carnival. A banner proclaims: SULTANA-THE ONE WHO READS YOUR FUTURE. Leaving my friends behind in the pavilion of the HALL OF MIRRORS, I enter into a magical world. I smell frankincense and myrrh in the parlor and eye a lot of weathered leather-bound books with golden squiggles on them.

I sit down on a low stool with bright, haphazardly embroidered cushions and extend my right hand, hesitantly, shyly. Everything she tells me is either wrong or untrue, but she seems so sure of the information that I begin to feel as if I'd been wandering around with these false documents permanently tattooed to my hand, forcing me to walk through life in a story not really my own. I stare at my own hand for a while, and realize that perhaps there is a translation problem here, for Arabic goes from right to left. I quickly withdraw my right hand and extend my left. She too puts a hand out, and we sit there for several minutes in what I assume is a ritual, until I realize that her hand is out waiting for the money.

\section{7}

In Benares, my mother made an appointment with an astrologer, to lift, if he could, my fortunes out of the morass. Since I had caused her enough unhappiness already, I went.

The astrologer was an overbearing man with a large belly, who sat on a bare raised wooden board in a room adorned by a single glossy calendar with an image of Shiva. He was known for "reading" people's futures from palmyra leaf scrolls written by a sage hundreds of years ago, a sage who asked the god Shiva for the destiny of each and every soul and wrote it down for posterity.

He patted the boards beside him. "Sit, daughter," he ordered, addressing me with some condescension, pulling out some dusty rolled-up scrolls from the shelf beside him. He laughed out loud. "So, you got entangled with a conman? Tell me, daughter, was it true love?" I weathered my mother's eyes boring a slow, fine hole into my face. I nodded, staring all the while at the floor.

My mother whined, "It's her future that I worry about. You see, this man has some documents in his possession..." The astrologer rocked with laughter. "Love letters, heh? And he intends to use them... most unscrupulous man, ha-haha. But never fear. Your daughter here has beauty and learning. The husband-tocome will be completely swept off his feet... but before that, we have to destroy the evil one's designs, don't we? Something must be done. Get me a coconut, Ram." An acolyte emerged from the shadows with a coconut wrapped in saffron cloth. He extended the coconut to me and instructed, "Now put your hands on it while I fix the hex; repeat after me: Kettai nakshatra... Vishwamitra gotra..." A mantra, a sprinkling of holy water, a red amulet for my wrists, and my mother opening her purse. 